\title{
An Africana womanist Reading of the Unity of Thought and Action
}

\author{
Nahed Mohammed Ahmed
}

\begin{abstract}
This article examines the importance of establishing an authentic African-centered paradigm in Black Studies. In doing so, this article selects Clenora Hudson-Weems' Africana womanism paradigm as an example. The unity of thought and action is the most important concept in this paradigm. The article tries to trace the main features of such a concept and how these features are different from these in other gender-based paradigms. Africana womanism, coming out of the rich and old legacy of African womanhood, then, is an authentic Afrocentric paradigm. Africana womanism is a term coined in the late 1980s by Clenora HudsonWeems. As a pioneer of such an Africana womanist literary theory, Hudson-Weems explains the term Africana womanism as follows: Africana means African-Americans, African-Caribbeans, African-Europeans, and Continental Africans. Womanism is more specific because "terminology derived from the word 'woman' is . . . more specific when naming a group of the human race" (“Africana Womanism: An Overview” 205-17).
\end{abstract}

Besides, womanism is a recall for Sojourner Truth's powerful speech, "And Ain't I a Woman " affirming that the Africana woman 's problem lies in being black and not in being a woman in which she was forced to speak about race issues because "she was hissed and jeered at because she was black, not because she was a woman, since she was among the community of women" (207).The present article uncovers the importance of Hudson-Weems' quest for an authentic Africana paradigm through shedding light on her concept of the unity between thought and action, used by earlier authentic Africana paradigms, namely Black aestheticism and Afrocentricity

In "Africana Womanism and the Critical Need for Africana Theory and Thought," Hudson-Weems clarifies her concept of the unity between thought and action. It is a call to adopt Africana thought-action-based paradigms that highlight what is African-centered, rooted in African culture, and directed towards the needs of the Africana communities as a whole. She urges Africana scholars to steer away from the dominant western theories which are created in favor of their communities' priorities and needs and which are not ready to locate the Afrocentric perspective at the forefront of reading and analyzing the problems and the specific experiences of the Africana communities in the Africana literary texts. In this respect, Afrocentricity is a case in point highlighting Africana womanism's African-centered view. Molefi Kete Asante gives a description of Afrocentricity as a scholarly approach that places African history and consciousness at the forefront of analysis: Now as an Afrocentricist I approach the construction of knowledge from the standpoint of Africans as agents in the world, actors, not simply the spectators to Europe. Since Afrocentricity constitutes a new way of examining data, a novel, orientation to data, it carries with it assumptions about the current state of the African world. One assumes for example that Africans are frequently operating intellectually, philosophically, and culturally off of African terms and therefore are dislocated, detached, isolated, decentered, or disoriented ("Afrocentricity: Toward a New Understanding"n.pag)."The standpoint of Africans as agents in the world, actors, not simply the spectators to Europe" means that, as Barbara Ransby clarifies, when you study black people from an Afrocentric perspective, you have to regard them as subjects that have roles in the creation of history and culture rather than "the passive recipients of someone else's actions (217). In other words, black people have to be regarded as cultural creators and not followers to the dominant culture.Greg Wiggan's comment on Asante's meaning of Afrocentricity as "placing African ideals at the center of any analysis that involves African culture and behavior," makes it clear that "any analysis" can be social, political or economic for shedding light on Africana people's suppressed contributions (131).That is, whatever the type of the analysis, Afrocentric ideas should be used as criteria for such an analysis. Besides Asante's definition of Afrocentricity, Maulana Karenga gives another definition. Karenga's definition is a clear orientation towards the unity of thought and action: "Afrocentricity. . . as a quality of thought and practice rooted in the cultural images and human interest of African people [and their descendants]. To be anchored in the views and values of African people as well as in the practice which emanates from and gives rise to these views and values" (Introduction to Black Studies 36). Here, he clarifies that Afrocentricity's thought is mainly rooted in the African culture and its action is for the Africana people.In this way, during the eighties, the focus on 'Afrocentricity' was a call for African-centered quests. Hudson-Weems makes it clear that Asante popularized the term 'Afrocentricity' as an authentic Africana paradigm (Africana Womanism 623). Concerning African-centered quests, Asante insists on the 
centrality of African interests, values, and perspectives against Eurocentric ideas in black life (Afrocentricity: The Theory of Social Change 2). In other words, the Afrocentric perspective is grounded in African world view, history, tradition, and agency.

Maulana Karenga also asserts the continual communication with Africa: "the ongoing dialogue with Africa" ("Black Studies: A Critical Reassessment" 164) and affirms Hudson-Weems and Asante's views of studying the Africana communities from an Afrocentric perspective when he says "there is no substitute for centering oneself in one's own culture and speaking one's own cultural truth" ("Black Studies: A Critical Reassessment 166). However, he clarifies that such an Afrocentric view does not mean that the Africana communities are in isolation or call for separatism. It is just a tool for bringing the special cultural truth to the table In other words, there are many realities other than the European one and each culture is specific in its own way. He adds his acceptance of "the multicultural society" which has the following characteristics: "Mutual respect for each people and culture; mutual respect for each people's right and responsibility to speak their own special cultural truth" (168). As this quotation reveals, these characteristics share respect as their keyword. Such characteristics echo Asante's statement concerning treating Africana people as "agents in the world, actors, not simply the spectators to Europe"("Afrocentricity: Toward a New Understandingn.pag). That is, Africana people should be treated as partners in this world. In this respect, we can say that Africana womanism is the other side of Afrocentricity or its "complement" (Hubbard, "When and Where I Enter" 288). Both Asante and HudsonWeems place African consciousness and history as a means to enlighten the community spirit through their authentic Africana thought-action-based paradigms. Hudson-Weems herself stresses that she is the female part or the other side, of Asante and other Afrocentric scholars because she, as a woman, is concerned with the issues of all women of African descent. But, like them, she adopts the Afrocentric view in her reading of Africana literary texts. She makes a comparison between herself and Afrocentric scholars, including Asante: "I take for my analysis of Africana texts an African-centered theory, grounded in Africana thought and action, and hence what I am proposing, like Afrocentric scholar Asante. . . and before him (Cheikh Anta Diop, John Henrik Clarke, and Chancellor Williams to name a few), is an Afrocentric perspective on Africana issues." (Africana Womanism 47)The Afrocentric perspective leads to a debate concerning the interdisciplinary perspective of Black Studies. Fabio Rojas argues that there is one school of thought that views Africana Studies as "a kind of interdisciplinary field" because they take American Studies as a model. American studies draw their "analytical framework" from relevant fields, such as Sociology and History. Rojas takes P. Dagbovie's The Early Black History Movement and M. Karenga's Introduction to Black Studies as examples of Africana scholars who argue that history is a core topic in Africana Studies (93). Hudson-Weems, as an Afrocentrist, refuses such an interdisciplinary perspective and insists on the existence of Africana Studies with its own approaches and its analytical framework. In "Africana Womanism and the Critical Need for Africana Theory and Thought," she confirms her opposition to the interdisciplinary perspective when she clarifies her concept of the unity between thought and action. Such an interdisciplinary perspective is an obstacle before the African-centered view which is the main idea of Hudson-Weems' concept of the unity between Africana theory and action. The interdisciplinary perspective does not achievethe authenticity of the Afrocentric paradigms. It isan obvious attempt followingthe European models,such as the model of American studies in our African-based paradigms. Hudson-Weems' explanation for the requirements of an authentic Africana model affirms the danger of such an interdisciplinary approach:We need our own Africana theorists, not scholars who duplicate or use theories created by others in analyzing Africana texts. Indeed, developing paradigms and critical theories, which is our true mission, makes possible for better monitoring interpretations of our works in an effort to keep them both authentic and accurate in order to maintain their originality in meaning and value. ("Africana Womanism and the Critical Need for Africana Theory and Thought" 79) In the same article, Hudson-Weems affirms her opposition to such an interdisciplinary perspective when she quotes Dr. Richard K. Barksdale's view of the Eurocentric approaches which are not race-centered ones and do not advocate the personal experience (by personal experience you mean culturally specific?): "We ignore deconstruction, post-structural textual exegesis and continental hermeneutics. African American literature cannot effectively survive critical approaches that stress authorial depersonalization and the essential unimportance of racial history, racial community, and racial traditions" (37-8).Also Ama Mazama criticizes such an interdisciplinary perspective on the basis that it brings traditional European disciplines to a discipline whose mission is the liberation of black people. Moreover, Mazama asserts that Afrocentricity is the only viable school of thought for Black Studies. According to her, "Africana Studies' greater autonomy will be achieved through a redefinition of the discipline not by subject matter, but by the systematic and consciousness adoption of a conceptual framework generated by Africana people" ("Interdisciplinary, Transdisciplinary, or Unidisciplinary?"12). This conceptual framework positively affects the community spirit because, as Asante and A. B. Assensoh reveal, the interdisciplinary perspective is not appropriate to privileging the experiences of Africana communities.Like Mazama, Asante, and A. B. Assensoh, Fabio Rojas views Afrocentricity as an alternative to the interdisciplinary practice being multidisciplinary or trans-disciplinary. Asante supports the idea that Afrocentricity is trans-disciplinary or 
multidisciplinary on the basis that a historian or an economist can use it as a criterion for evaluating their research (Rojas 93). Such an alternative perspective is in favor of the unity between Africana thought and action because it brings an authentic Africana theory to the unique conditions of Africans and the African Diaspora (Asante, The Afrocentric Idea). In her quest for an authentic Africana thought-action-based paradigm, Hudson-Weems focuses on the concept of collectivism, communalism being a characteristic of African culture. She claims that such a communal aspect is an African concept and legacy: "As we've always done as Africans: A people collectively working. We come from a communal past. "It takes a village to raise a child," as the old African adage goes. Well, it takes a village to do everything, because we work together" (Hudson-Weems, Unpublished personal interview page \#). Daphne W. Ntiri affirms such a focus on communalism as a value related to Africana communities in her comment on the similarity between Patricia Hill Collins' anti-feminist thoughts in "What's in a Name? Womanism, Black Feminism and Beyond" and Hudson-Weems' earlier works. She explains that "[t]he Practice of feminist ideology is based on individualism rather than communalismLifestyles and values more akin to African Americans and their ancestry" ("Reassessing Africana Womanism" 164).In "Africana Womanism and the Critical Need for Africana Theory and Thought," Hudson-Weems criticizes the individualistic spirit in her disagreement with critics,such as Lentricchia who support individualbased theories and individual empowerment(Barksdale37) LaRese C. Hubbard affirms Hudson-Weems' claim that the communal aspect is an African concept through shedding light on the communal aspect between black men and women: "It was not too distant from an African conception to see women and men as partners, that is, as different in their perspectives, roles, and sensibilities but equal as human beings. This was the African way of looking at femininity and masculinity" ("When I and Where I Enter" 288).Besides the Afrocentric perspective and the concept of collectivism, Hudson-Weems also believes that art has to have a function for the unity between Africana theory and action. The functionality of art is against the European idea of the aesthetic value of art, and the concern with form and structure rather than content, such as the European theory ofFerdinand de Saussure. According to Hudson-Weems, Ferdinand de Saussure's approach is inapplicable to Africana textual analysis because it is concerned with the structural analysis of language and not the historical one. HudsonWeems' argument stems from Saussure's definition of the system of language. He defines it as system of signs/words which contain a signifier (the word itself) and the signified (the meaning of the word).He also adds that there is a difference between the language as a system and the uses of language whether these uses are written or spoken. To him, language does not reflect reality. When calling a thing a tree, it does not necessarily make it so. He makes it clear that: "a sign is not a link between a thing and a name, but between a concept and a sound pattern" (Course in Linguistics 66). In this way, he is concerned with the form and the structure of signs and not with their social content or context. To Hudson-Weems, social context is more important and should be focused on by the Africana critics in their reading of the Africana texts which reflect the reality of the Africana communities' experiences and struggles as oppressed people ("Africana Womanism and the Critical Need for Africana Theory and Thought "79). In this way, Hudson-Weems affirms her belief in the coexistence of art and propaganda through her interest in the importance of the historical, political, and social context of Africana literature and through her quotation of her mentor, Dr. Richard K. Barksdale's criticism of the American theorists who adopt "French-based theories of textual criticism". Such theories exclude the historical and personal experiences, emphasizing just what he describes as a "sense of intellectual mystification" (36). In fact, Hudson-Weems completes what other Africana scholars, such as W. E. B. Du Bois, Amiri Baraka and Larry Neal and Asante have started in relation to the functionality of Art and consequently the unity between Africana theory and action. As for Du. Bois, he is the first to support the functionality of Art. In "Criteria of Negro Art," $\mathrm{Du}$ Bois reveals that Art and propaganda are one,explaining that the artistic works about Blacks should be directed towards their need for equality with their western counterparts: Thus, all art is propaganda and ever must be, despite the wailing of pursuits. I stand in utter shamefulness and say that whatever art I have for writing has been used always for propaganda for gaining the right of black folk to love and enjoy. (296) In fact, the Black Arts Movement of the sixties builds on Du Bois' idea and Larry Neal advocates it in the anthology, Black Fire: "The artist and the political activist are one" (656). The Black Arts Movement or BAM is the artistic branch of the Black Power Movement. These two movements are clear examples of the unity between thought (the revival of black culture) and action (the political action). BAM, which started in Harlem by the writer and activist Amiri Baraka,was a cultural revolution against the western cultural system as a whole led by Amiri Baraka, Larry Neal, and others. In "The Black Arts Movement," Neal argues, "the cultural values inherent in Western history must either be radicalized or destroyed. In fact, what is needed is a whole new system of ideas" (258). The Black Arts Repertory Theatre was a key institution of the Black Arts Movement for two main reasons. First, it helped the movement to achieve its main aim of destroying the western cultural system. The theatre presented plays that "shattered the illusions of the American body politic, and awakened Black people to the meaning of their lives" (Neal 262). Second, it achieved the social function of art. Neal explains that plays about blacks were "directed at problems within Black America" (273).BAM's refusal of the ideas of assimilation and integration within the western culture lead to the black aesthetic theory whose main 
goal was to revive the black experience. In Chicago, the Organization of Black American Culture (OBAC) moved toward a definition of the blackaesthetic. It aimed at publishing an anthology in order to clarify this aesthetic. In that anthology, after establishing criteria for judging their artistic work, the writers of OBAC "eliminate from consideration those poems, short stories, plays, essays and sketches which do not adequately reflect the black experience" (Fuller 9). Patricia Liggins Hill's definition of the black aesthetic is in agreement with the writers of OBAC's orientation. Hill defines it as "a black criterion for judging the validity and/or beauty of a work of art..."(1365).

Africana womanists' mission is similar to that of OBAC's writers. Both of them create their own criteria for evaluating their own experiences. With respect to Africana womanists' mission, HudsonWeems states that they create "criteria for assessing realties, both in thought and in action" (Africana Womanism 50).Asante also agrees with DuBois' idea of the function of black art. In Asante's attempts to unify between thought and action, he understands that African art has to have a message: "African art is never l'art pour l'art; it is always functional" (The Afrocentric Idea 75). In other words, black art is part of life. It cannot be separated from it. Therefore, it has to be a mirror of its society. Even in his definition of blackness, he defines it in relation to its function and mission. Blackness is not a trope of aesthetics, but "trope of ethics". That is "to be black is to be against all forms of oppression, racism, patriarchy, child and white racial domination" (Asante, Afrocentricity: The Theory of Social Change2).This justifies the way Hudson-WeemsregardedBlack aestheticism of the sixties and Afrocentricity of the eighties and later Africana womanism as the authentic Africana thought-action-based paradigms. Like Africana womanism, Black aestheticism and Afrocentricity's thoughts are oriented towards the cultural connection to Africa. So, they take its values and concepts at the basis ofassessing Africana experiences. Besides, they are the first supporters of the functionality of art.HudsonWeems regards black aestheticism as one of the authentic paradigms for Africana Studies due to its black cultural grounding ("Africana Thought-Action: An Authenticating Paradigm for Africana Studies" 622). This black cultural grounding is what links between Toni Morrison and Zora Neale Hurston in spite of their belonging to different periods of back writing. As Nada Ella shows, both writers belong to "the black aesthetic tradition" (50).Such Africana scholars as W. E. B. DU Bois, Amiri Baraka, Larry Neal, Asante and HudsonWeems helped create authentic Africana paradigms because of their insistence on the unity between their thought and action represented by their choice of the Afrocentric perspective as criterion for reflecting the realities of their communities. So, Hudson-Weems regards repeating and copying the European theories where their thoughts and actions are just directed towards the problems and issues of their communities as a main obstacle before the unity between an Africana thought and action.Hudson-Weems cites examples of these European theories which include feminism, black feminism, womanism, and even African feminism. That is why, when she defines Africana womanism, she clarifies that Africana womanism's thought is different from feminism. Consequently, their action is also different: "Neither an outgrowth nor an addendum to feminism, Africana Womanism is not Black feminism, African feminism, or Walker's Womanism" (Hudson-Weems, Africana Womanism 24). That is Africana womanism is family-centered and constitutes a quest for race empowerment, while feminism is female-centered and focusing on a quest for female empowerment. In "Africana Womanism: The Flip Side of a Coin,"Hudson-Weems reads Mariama Bâ's So Long a Letter as an example of the centrality of family: "The success of a nation therefore depends inevitably on family" (8889).Many western feminists affirm the inadequacy of feminism to Africana communities. For example, Betinna Aptheker thinks that feminism is not valid to the black women experience. She explains that

[w] hen we place women at the center of our thinking, we are going about the business of creating an historical and cultural matrix from which women may claim autonomy and independence over their own lives. For women of color, such autonomy cannot be achieved in conditions of racial oppression and cultural genocide. In short, "feminist," in the modern sense, means the empowerment of women. For women of color, such an equality, such an empowerment, cannot take place unless the communities in which they live can successfully establish their own racial and cultural integrity. (13)

In an unpublished personal interview with Hudson-Weems, Pamela YaaAsantewaa Reed uncovers Hudson-Weems' views on feminist theories. She reveals that theories, such as feminism, have not been adequate enough in expressing the real black experience and its cultural reality. Its agenda is clearly for the western woman's problems. In this respect, Nah Dove agrees with Hudson-Weems in the specificity of African women's experience. In "Defining African Womanist Tradition," she states that "While my focus was on conceptualizing and defining the racialization of the world through European domination/White supremacy, it was impossible to ignore the specificity of oppression of African women living in male-centered Western society" (165). In such a "male-centered Western society," Hudson-Weems clarifies that black man's power is not like the white man's. The former does not have "the same institutionalized power to oppress Africana women as white men have had to suppress white women" (Africana Womanism 23). In this way, even the gender issues in the Africana communities are different from western ones. Hudson-Weems reflects such a difference in her comment on western women's reaction to The Fifteenth Amendment to the Constitution of the 
United States of 1870 which grants African men the voting rights, while denying that privilege for white women. It is a reaction reflecting western women's search for individualistic rights which are not part of Africana womanism's agenda. Their agenda is race-centered and it is a focus on the positive relations between black men and women: "Unlike Black women, who were jubilant with this victory for the Black race, as they know that a vote in the Black community could only improve things for them in general, White women were disappointed" ("Africana Womanism: The Flip Side of a Coin" 139).

Hudson-Weems also points to the conservative suffragist leader Carrie Chapman Catt's racist reaction on black men's voting rights through her view of the inferiority of blackness. She, and other white women, "insisted upon strong Anglo Saxon values and White supremacy, excluding not only Africanans but White immigrants as well" (Africana Womanism 21). Also she clarifies some other western women's racist attitudes when they founded The National Woman Suffrage Association, and insisted on the necessity of white women's vote in order to help white men against the threat of black men: "Unqualified and biological inferiors, who with the voting power could acquire the political power within the American system" ("Africana Womanism: An Overview" 207).In reaction to such specific treatment of gender and also for the sake of the unity between an authentic Africana thought and action, Hudson-Weems considers her theory about Africana women to be a part of Africana studies because her action will be directed to the whole community, or rather Africana woman's relation to her community: "Given that ethnic identification precedes gender identity in the name Africana Women's Studies, it seems plausible that the race factor is more crucial" (Africana Womanism 77). This means that the separation between Africana studies and Africana women's studies is not appropriate to Africana womanism's concept of unity between thought and action.

In "Black Women's Studies: The Interface of Women's Studies and Black Studies," B. Guy-Shefthall clarifies such a different perspective and aim between the two studies through clarifying the area of research for both Black women's Studies and Black Studies. In Black Women's Studies, the focus is on the influence of racism and sexism on black women while in Black Studies, the focus is on black women's role within the black family and on the public lives of notable black women, such as Sojourner Truth and Harriet Tubman as an affirmation of their effective contributions in black history. In other words, Black Studies investigates black women's relation to their community while Black women's Studies focuses on black female experience (2).GuyShefthall's clarification is further elucidated in Patricia Bell Scott's argument that there is a need for investigating the effects of racism and sexism on black women.In the introduction of But Some Of Us Are Brave: All the Women Are White, All the Blacks Are Men: Black Women's StudiesBlack feminist scholars, Gloria T. Hull and Barbara Smith also explain that their feminist view is able to develop black women's consciousness: "Only a feminist, pro-woman perspective that acknowledges the reality of sexual oppression in the lives of Black Women, as well as the oppression of race and class, will make Black women's studies the transformer of consciousness it needs to be" (xxi), and accordingly,Afrocentricity adopts Africana Womanism as the main paradigm in incorporating women of African descent (Phillips, "Black Studies" 274). Such an adoption is due to Africana womanism's ideology. Hudson-Weems defines it as"[a]n ideology created and designed for all women of African descent. It is grounded in African culture, and therefore, it necessarily focuses on the unique experiences, struggles, needs, and desires of Africana women...Its primary goal...is to create their [Africana women's] own criteria for assessing their realities , both in thought and in action" (Africana Womanism48-50). That is, Africana womanism's thought and action is mainly Afrocentric and for all women of African descent. It is keen on creating Afrocentric criteria which enable Africana women to express their realities in an authentic way.

Butblack feminism's thought and actionis different from Africana womanism's one. According to Hudson-Weems, black feminism's thought and action is different from Africana womanism in many ways. Sheexplains black communities' unsatisfactory view of black feminists: [T] hey [i.e., Africana women and men] hold to the opinion that those Africana women who embrace the feminist movement are mere assimilationists... who have no true commitment to their culture or their people" (Africana Womanism 26). Describing them as "assimilationists" means that black feminists are not completely supporters to the Afrocentric perspective or have no true commitment to their people who are the main steps for the unity between Africana theory and thought.Consequently, they are different from Africana women.

Hudson-Weems also affirms Africana womanism's difference from black feminism through criticizing their useof the name of the European theory, feminism. Itis an indication of Hudson-Weems' awareness of the necessity of self-naming which is the first characteristic of Africanawomanism.In this respect, in Marshall's Praise Song for the Widow, Hudson-Weems raises the question of self-naming. Here the protagonist, Ava Johnson, comes to accept her authentic name, Avatara ("Africana Womanism: The Flip Side of a Coin 141). So, her acceptance of her real name is an indication of her desire of defining herself as an Africana woman. Unlike Black feminists Africana womanists cannot name themselves after somebody else: "To name myself after a theory that came after me, that actually used me as a blueprint. That's what black women do, when they call themselves Black Feminists, when actually, we were the blueprint for the feminists" (Hudson-Weems, 
Unpublished Personal interview).In fact, Hudson-Weems' focus on self-naming also leads her to criticize African feminism, revealing that when one "buys the White terminology, she also buys its agenda" ("Cultural and Agenda Conflicts in Academia"187). In this way, Africana womanism views the acceptance of naming after somebody else as an obstacle before the unity between Africana thought and action because it is the first step towards ignoring and alienating the Africana womanist from the realities and needs of her community and its priorities.Womanism, as an African or black form, it is used by three theorists. First, Alice Walker's womanism presented in her collection of essays, In Search of our Mothers'Gardens. Second, Chikwenye Okonjo Ogunyemi's African womanism introduced in her article, "Womanism: The Dynamics of the Contemporary Black Female Novel in English." Third, Hudson-Weems' Africana womanism presented in various papers and in her seminal work, Africana Womanism: Reclaimimg Ourselves

In "Kawida Womanism: African ways of Being Woman in the World," Tiamoyo Karenga and Chimpuko Tempo criticize Walker's concept of womanism because ofusing feminism as the central point of reference instead of the historical development of African womanhood: "It does not speak to the full range of ways of being an African woman in the world and does not speak to the long history in which the conception of the African woman evolves in its diversity" (35).In this respect, Hudson-Weems' concept of womanism is in accordance with Tiamoyo Karenga and Chimpuko Tempo. She clarifies that Africana womanist activism is a part of a cultural inheritance when she articulates the authentic agenda of her Africana womanist theory which dates back to the rich legacy of African womanhood ("Africana womanism: An overview" 210). In this way, Hudson-Weems incorporates the experiences of black women outside of the US through her diasporic vision. Consequently, she keeps the Afrocentric perspective as a basic element of unifying Africana theory and action. Hudson-Weems is also against Alice Walker's concept of womanism because she does not develop it. In, In Search of our Mothers' Gardens, Walker defines womanism, affirming such lack of development and such a close relation between feminism and her concept of womanism: "Womanist is to feminist as purple to lavender" (xii).Also the editor of Call and Response: The Riverside Anthology of the African American Literary Traditionshows such lack of development in commenting on Alice Walker's womanism and its relation to black feminism, revealing that "there is little difference between the womanist and the black feminist" (1378-1379).

Hudson-Weem's Africana womanism is more developed because of the collective struggle of both Africana man and woman. In this respect, Patricia Liggins Hill comments on Hudson-Weems' priorities. She explains that her priorities are family-centeredness, race and class empowerment and the other gender-based theories are female-centerednessand gender empowerment (335-45). Her interest in such priorities is clear when she explains"we (Women of the African Diaspora) are not playing with gender issues-we are dealing with real life issues which do not exclude gender but deal with securing and empowering our people" (HudsonWeems, "Africana Womanism: Ties to the Destiny of a People" 3). In other words, shedoes not neglect gender issues, but she searches for an Africana womanist manner of addressing them ("Africana Womanism: An Overview" 206). In unpublished personal interview, Hudson-Weems shows such an Africana womanist perspective when she advocates the collective work between Africana men and women even in gender issues: I deal with it [gender] authentically. I am not anti-male. My daddy was a male. My husband is a male. I have cousins, friends, whatever who are male. I'd be the last one to exclude a male from a discussion because he's a male. They should be welcomed instead of excluded from the meetings or discussions on gender issues. Another evidence of her focus on the race factor is clear in her article, "Africana Womanism: An Overview" when she quotes two black sociologists, Vivian Gordon and Delores Aldridge's views of addressing Africana women's issues. The former focuses on black women's relation to their children and how their mothers prepare them for their responsibilities in the future while the latter focuses on the relations between black men and women. Such positive relations between children and their mothers on one hand and black men and women on the other hand are of course steps for race empowerment.

In a continual quest for the unity between Africana theory and thought, Africana womanism highlights eighteenth characteristics of the Africana womanist. These eighteen characteristics come from the rich legacy of African womanhood and culture. In this way, Africana womanism assesses Africana literary texts from an Afrocentric perspective, unifying between Africana womanists' thought (an African-centered, familycentered, and communal) approach and their action (the analysis of the Africana texts) to reach a cultural textual analysis. These characteristics are self-naming, self-definition, role flexibility, family centeredness, struggling with males against oppression, adaptability, black female sisterhood, wholeness, authenticity, strength, male compatibility, respect, respect for elders, ambition, mothering, nurturing, and spirituality. In this way, these characteristics are the touchstones for the Africana woman's relation to her community which stems its power from African ideals and values.

To sum up, Africana Womanisms concept of the unity of thought and action has six distinctive features: First, it is a humanist and communal approach. It does not align itself with a certain sector in the Africana community but rather maintains relations with women, men, and children.In other words, it is familycentered. It is concerned with the liberation of the entire Africana community: women, men, and children. 
Second, it is African-centered. In this way, Africana womanism reading is based on an Afrocentric ideology and not a European one. Third, it is totally different from Western feminism and any other feminist theories, such as black feminism and African feminism. Fourth, it is also differentfrom other womanist ideologies which use "womanism" as a term in the black intellectual tradition, such as Alice Walker's womanism. Fifth, unlike other gender-based theories, its priorities are race, class, and gender. Finally, this concept of the unity of thought is against the approaches that destroy the personal experience, such as deconstruction and poststructuralism.

\section{WORKS CITED}

[1] Asante, MolefiKete (1983). The Afrocentric Idea. PA: The University of Pennsylvania Press. (2003). Afrocentricity: The Theory of Social Change. Chicago: African American Images.

[2] Assensoh, A. B. (2003). "Race in the Academy: Moving beyond Diversity and toward the Incorporation of Faculty of Color in Predominantly White Colleges and Universities." The Journal of Black Studies 34, 52-62.

[3] Barksdale, Richard K (1992). "Critical Theory and Problem of Canonicity in African American Literature." Praisesong of Survival. Urbana and Chicago, Illinois: Illinois UP,. 32-38.

[4] Dagbovie, Pero Gaglo(2007). The Early Black History Movement, Carter G. Woodson, and Lorenzo Johnston Greene. University of Illinois Press: New Black Studies Series.

[5] Du Bois, William Edward Burghardt(1926). "Criteria of Negro art." Crisis 32, (6), 290297.Fuller, Hoyt W (1972). "Towards a Black Aesthetic.” The Black Aesthetic. EdAddison. 3-11.

[6] Hudson-Weems, Clenora(1997). "Africana Womanism and The critical Need for Africana Theory and Thought." The Western Journal of Black Studies 21,(2), 79-84.

[7] (1993). Africana Womanism: Reclaiming Ourselves. Troy: Bedford. Hill, Patricia Liggins, ed(1998). Call and Response: The Riverside Anthology of the African American Literary Tradition. Boston and New York: Houghton Mifflin Company.

[8] Karenga, Maulana(1982). Introduction to Black Studies. Los Angeles: Kawida.Mazama, A (2006). Interdisciplinary, Transdisciplinary, or Unidisciplinary? Africana Studies and the Vexing Question of Definition."Handbook of Black Studies. Eds. M.Asante and M.Karenga. Thousand Oaks: Sage Publications,. 3-15.

[9] Neal, Larry (1972). "The Black Arts Movement.” The Black Aesthetic. Ed. Addison Gayle, Jr. Garden City: Anchor Books. 257-74.

[10] (1968). "And Shine Swam On.” Black Fire: An Anthology of Afro-American Writing. Eds. LeRoi Jones and Larry Neal. New York: William Morrow and Company,. 637-656

[11] Rojas, Fabio (2011). "Instituations and Disciplinary Beliefs About Africana Studies." The Western Journal of Black Studies 35, (2), 92-105

[12] Saussure, Ferdinand de (1983). Course in General Linguistics. Translated by Roy Harris. La Salle: Open Court. 